\title{
COVID-19 Pandemisi Sürecinde Artan El Hijyeni Uyumunun Gögüus Hastalıkları Yog̃un Bakım Ünitesindeki Kültür Sonuçlarına Etkisi
}

\section{The Effect of Increased Hand Hygiene Adaptation to Chest Diseases Intensive Care Unit Culture Results during COVID-19 Pandemic Process}

\author{
Mustafa TOSUN' (IDD), Umut Devrim BINAY² (iD), Sümeyye AKYÜZ3 (ID), Hasan ÖLMEZ' (ID), Faruk KARAKEÇILi (ID) \\ ${ }^{1}$ Erzincan Binali Yıldırım Üniversitesi Tıp Fakültesi, Gög̃üs Hastalıkları Anabilim Dalı, Erzincan, Türkiye \\ ${ }^{2}$ Erzincan Binali Yıldırım Üniversitesi Tıp Fakültesi, İnfeksiyon Hastalıkları ve Klinik Mikrobiyoloji Anabilim Dalı, Erzincan, Türkiye \\ ${ }^{3}$ Erzincan Binali Yıldırım Üniversitesi Tıp Fakültesi, Tıbbi Mikrobiyoloji Anabilim Dalı, Erzincan, Türkiye
}

Makale atıfi: Tosun M, Binay UD, Akyüz S, Ölmez H, Karakeçili F. COVID-19 pandemisi sürecinde artan el hijyeni uyumunun göğüs hastalıkları yoğun bakım ünitesindeki kültür sonuçlarına etkisi. FLORA 2021;26(4):584-93.

\section{ÖZ}

Giriş: Sağlık hizmeti ilişkili infeksiyonların (SHii) en sık görüldüğü birimler yoğun bakım üniteleridir. El hijyeni SHii'lerin önlenmesinde kritik role sahiptir. Erzincan Binali Yıldırım Üniversitesi Tıp Fakültesi Göğüs Hastalıkları Yoğun Bakım Ünitesi'nde (YBü) yatan hastaları COVID-19 öncesi ve sonrası olmak üzere iki gruba ayırarak değerlendirdik. Çalışmamızda pandemi ile birlikte sağık çalışanlarında artan el hijyeni uyumunun kültür sonuçlarına etkisini ölçmeyi ve el hijyeninin önemini vurgulamayı amaçladık.

Materyal ve Metod: Hastalar, 4 aylık dönemler halinde iki grupta incelendi. 15 Kasım 2019-15 Mart 2020 tarihleri arası COVID-19 öncesi ve 16 Mart 2020-15 Temmuz 2020 arası ise COVID-19 sonrası dönem olarak ele alındı. Bu hastalardan alınan kültür sayıları ve üretilen etkenler tespit edilerek alınan kültür sayııına göre üreme oranındaki değişsim, direnç oranları, yoğun bakım yatış süreleri, entübasyon gün süreleri ve mortalite oranları karşılaştırılmıştır.

Bulgular: Pandemi Öncesi (PÖ) grubunda 40 kadın (\%46.5), 46 erkek (\%53.5) vardı ve yaş ortalaması $71.5 \pm 14.8$ idi. Pandemi Sonrası (PS) grubunda ise 38 kadın (\%38.8), 60 erkek (\%61.2) vardı ve yaş ortalamaları $72.6 \pm 14.8$ idi. PÖ grubunda 86 hastadan alınan toplam 605 kültürün 128'inde (\%21), PS grubunda ise 98 hastadan alınan toplam 304 kültürün 31 'inde (\%10.2) etken üretilmiştir. Alınan kültür sayısı, etken izole edilen kültür sayısı ve alınan kültüre göre üreme yüzdesi açısından iki grup karşılaştırıldı̆̆ında PÖ grubunda tüm parametreler PS grubuna göre anlamlı seviyede yüksek bulunmuştur (sırasılyla $p<0.001, p=0.002, p=0.001$ ).

Sonuç: Sonuç olarak her ne sebeple olursa olsun, el hijyeni uyumundaki artış kültürlerde üreyen etken mikroorganizma ve dolaylı olarak SHii'lerin azalması ile sonuçlanmış olabileceği düşünülmüştür. Bu nedenle özellikle yoğun bakımdaki çok ilaca dirençli (ÇiD) infeksiyonIarın önlenmesi amacıyla atılması gereken ilk adım să̆lık çalışanlarının el hijyeni uyumunun sağlanmasıdır.

Anahtar Kelimeler: COVID-19; Yoğun bakım; Kültür; El hijyeni

\section{ABSTRACT}

Geliș Tarihi/Received: 09/03/2021 - Kabul Ediliș Tarihi/Accepted: 02/07/2021 


\title{
The Effect of Increased Hand Hygiene Adaptation to Chest Diseases Intensive Care Unit Culture Results during COVID-19 Pandemic Process
}

\author{
Mustafa TOSUN', Umut Devrim BINAY², Sümeyye AKYÜZ³, Hasan ÖLMEZ1', Faruk KARAKEÇILi²
}

\footnotetext{
${ }^{1}$ Department of Chest Diseases, Erzincan Binali Yıldırım University Faculty of Medicine, Erzincan, Turkey

${ }^{2}$ Department of Infectious Diseases and Clinical Microbiology, Erzincan Binali Yıldırım University Faculty of Medicine, Erzincan, Turkey

${ }^{3}$ Department of Medical Microbiology, Erzincan Binali Yıldırım University Faculty of Medicine, Erzincan, Turkey
}

Introduction: Intensive care units are units where healthcare associated infections (HAls) are most common. Hand hygiene plays a critical role in preventing HAls. We divided the patients hospitalized in Erzincan Binali YIldrrm University Faculty of Medicine, Chest Diseases Intensive Care Unit (ICU) into two groups as before and after COVID-19 pandemic. In our study, it was aimed to measure the effect of hand hygiene compliance, which increased in healthcare workers with the pandemic, on culture results and to emphasize the importance of hand hygiene.

Materials and Methods: Patients were examined in two groups in 4-month periods. The period between 15 November, $2019-15$ March, 2020 was considered as before COVID-19 and between March 16, 2020 and 15 July, 2020 as after COVID-19. The number of cultures taken from these patients and the agents isolated were determined, and according to the number of cultures taken, the change in growth rate, resistance rates, length of stay in intensive care unit, intubation days and mortality rates were compared.

Results: There were 40 females (46.5\%) and 46 males (53.5\%) in the Pre-Pandemic (PreP) group, and mean age was $71.5 \pm 14.8$ years. In the Post-Pandemic (PostP) group, there were 38 females (38.8\%) and 60 males (61.2\%) with a mean age of $72.6 \pm 14.8$ years. The agent was reproduced in 128 (21\%) of a total of 605 cultures taken from 86 patients in the PreP group, and in 31 (10.2\%) of a total of 304 cultures from 98 patients in the PostP group. When the two groups were compared in terms of the number of cultures, the number of agent-isolated cultures and the percentage of growth according to the cultures, all parameters in the PreP group were found to be significantly higher than the PostP group ( $p<0.001, p=0.002, p=0.001$, respectively).

Conclusion: As a result, for whatever reason, it is thought that the increase in hand hygiene compliance may have resulted in a decrease in active microorganisms in the cultures and indirectly in the decrease in HAls. For this reason, the first step to be taken in order to prevent multi-drug resistant (MDR) infections, especially in intensive care units, is to ensure hand hygiene compliance of healthcare workers.

Key Words: COVID-19; Culture; Hand hygiene; Intensive care

\section{Giriș}

Sağlık hizmeti veren tesislerde hastalık olușturan mikroorganizmalar ile sik karșlașılması sebebiyle sağllk hizmeti ilișkili infeksiyonların (SHiil) gelișme riski yüksektir. Patojenler diğer hastalardan, hastane personelinden ve/veya hastane ortamından bulașabilir. Bir sağlı tesisinde coklu ilac direnci olan ve yüksek virulanslı mikroorganizmaların hastalar arasında yayılmasının sebebi yaklașık \%40 oranında sağllk çalıșanlarının kirli elleridir. Bu sebeple el hijyeni uyumu infeksiyonları önemli ölçüde engelleyebilir ${ }^{[1]}$. İnfeksiyöz bir ajanın varlığı belirgin olmasa bile, tüm hastaların bakımı için standart önlemler alınmalıdır. Bu standart önlemlerin bașinda ise el hijyeni gelmektedir ${ }^{[2,3]}$.

El hijyeni ellerin su ve sabun ile yikanması ya da alkol içeren bir el antiseptiği ile ovularak geçici floranın uzaklaștırılması ile sağlanır. Doğru teknikle el yıkamanın yanında ne zaman el yıkamanın gerektiğinin bilinmesi, yıkama ürünlerinin seçimi, ellerin yıkamaya elverișli olması, kurulama ve doğru eldiven kullanımı el hijyeninin ayrılmaz parçalarıdır ${ }^{[4]}$. El hijyeni için sabun veya alkol bazlı el antisepsisi kullanılabilir. Çoğu durumda alkol bazlı el antisepsisi tercih edilmektedir. Cünkü ellerin sabun ve suyla yıkanmasından daha kolay ve daha etkilidir ${ }^{[5,6]}$

Sağllk calıșanlarının el hijyenine uyumu uzun süredir devam eden bir sorundur. Coğu calıșma, el hijyeni uyumunun izleme ve anında geri bildirimle iyileștiğini göstermiștir. Ancak bu yaklașım zaman ve kaynakların tüketilmesine yol açmaktadır ${ }^{[7,8]}$.

COVID-19 pandemisi nedeniyle toplumda ve hastanelerde el hijyenine uyum artmıstır ${ }^{[9,10]}$. Art- 
miș uyum ile birlikte kültürlerde etken mikroorganizmaların üremesinde azalma ve dolaylı olarak SHï'yi önlemede etkili olabileceği düșünuilmektedir. Biz çalıșmamızda artmış el hijyeni uyumunun göğuis hastalıkları yoğun bakım ünitesindeki (YBÜ) kültür sonuclarına etkisini (kültürde üreme oranları, izole edilen etkenlerin değișimi ve izolatların direnc oranları) irdelemeyi amaçladık.

\section{MATERYAL ve METOD}

Calıșmaya Erzincan Binali Yıldırım Üniversitesi Tıp Fakültesi Göğüs Hastalıkları YBÜ'de 15 Kasım 2019-15 Mart 2020 (COVID-19 öncesi) ve 16 Mart 2020-15 Temmuz 2020 tarihleri (COVID-19 sonrası) arasında yatarak tedavi gören tüm hastalar dahil edilmiștir. Hastaların yas, cinsiyet gibi demografik verileri, hastaneye yatıs tanısı ve ek hastalıkları kaydedilmiștir. Hastaların yatıșları sırasında acil serviste hesaplanan quickSOFA (qSOFA) skorları, yoğun bakıma giriște ölçuilen tam kan, biyokimyasal parametreler, laktat, C-reaktif protein (CRP), prokalsitonin gibi infeksiyonu göstermede önemli olan parametreler kaydedilmiștir. Hastaların YBÜ'ye yatıs sebepleri, YBÜ'de kalıs süreleri, entübe edilen hastaların entübasyon gün süreleri ve mortalite oranları kaydedilmiștir. Ayrıca bu hastaların tıbbi mikrobiyoloji laboratuvarına gönderilen kan, trakeal aspirat, idrar, balgam, yara, kateter kültürleri kaydedilmiștir. Her iki gruptaki hastalardan alınan kültuir sayıları, kültürde üreme oranları, izole edilen etkenlerin değișimi ve izolatların direnç oranları karșılaștırılmıștır. Laboratuvara otomatize kan kültür sisesinde (BioMerieux, Fransa) gelen kan örnekleri bekletilmeden BacT/Alert 3D (BioMerieux) cihaz1na yüklenmiș ve beș günlük süreyle inkübasyona bırakılmıștır. Kan kültürü dıșındaki örneklerden idrar ve trakeal aspirat örnekleri kantitatif olarak, diğerleri ise tek koloni ekim yöntemiyle \%5 koyun kanl, EMB agar ve örnek türüne göre cikolata besiyerine (BioMerieux, Fransa) ekilmiștir. Üreyen kolonilerin identifikasyonu "Matriks assisted lazer desorption ionization time of flight massspectrometry" (MALDI-TOF MS Vitek MS sistemi, BioMerieux, Fransa) sistemiyle, antibiyotik duyarll11k calıșmaları ise Vitek 2 Compact (BioMerieux, Fransa) otomatize sistemiyle yapılmıștır. Duyarlılık sonuçarının raporlanmasında "European Commit- tee on Antimicrobial Susceptibility Testing" (EUCAST) kriterleri baz alınmıștır ${ }^{[11]}$.

Calıșmamızda el hijyeni uyumunun değerlendirilmesi İnfeksiyon Kontrol Komitesi (EKK)'nin el hijyeni uyumunun tespiti amacıyla düzenli olarak tutmuș olduğu güncel "el hijyeni uyum formu" kayıtları incelenerek elde edilmiștir. Bu form doğrultusunda YBÜ'de tüm personeli (doktor, hemșire, temizlik personeli vb.) kapsayacak sekilde en az haftada bir kez yapilan el hijyeni gözlemleri incelenmiștir. Ana hatlarıyla tarih, bașlama/bitis saati, gözlem süresi ile birlikte endikasyon durumu (el hijyeni için 5 endikasyon), eylemin ne sekilde yapıldığı (ovma, yıkama, yok ve eldiven) bu form ile değerlendirilmiștir. El hijyeni sağlanmadan sadece eldiven kullanımı uyumsuzluk olarak kayıt edilmiștir.

Calıșma için Erzincan Binali Yıldırım Üniversitesi Klinik Araștırmalar Etik Kurulu tarafından 28/01/2021 tarihli ve 03/01 sayılı kararıla onay almıștır.

\section{İstatistiksel Analiz}

İstatistiksel analiz IBM SPSS ver.19 kullan1larak yapild1. (IBM Corp., Armonk, NY, ABD). Sonuçar kategorik değișkenler için sayı ve yüzde, sürekli değișkenler için ortalama \pm standart sapma, ortanca ve minimum-maksimum olarak sunuldu. Kategorik değișkenlerin gruplar arasında karșlaștırılması Ki-kare veya Fisher kesin testi ile yapıldı. Sürekli değișkenler için normal dağılım Kolmogorov-Smirnov testi ile doğrulandı. Bağımsız sürekli değișkenlerin iki grup arasında karșılaștırilmasında Student's t-testi veya Mann-Whitney U testi kullanıldı. Tüm testler için istatistiksel anlamlilık düzeyi 0.05 olarak kabul edildi.

\section{BULGULAR}

COVID-19 öncesi 86 hasta, COVID-19 sonras1 98 hasta olmak üzere Erzincan Binali Y1ld1rım Üniversitesi Tıp Fakültesi Göğuis Hastalıkları YBÜ'de yatan toplam 184 hasta calıșmaya dahil edilmiștir. Pandemi öncesi (PÖ) grubu 40 kadın (\%46.5). 46 erkek (\%53.5) ve yaș ortalaması $71.5 \pm 14.8$ iken, pandemi sonrası (PS) grubu ise 38 kadın (\%38.8), 60 erkek (\%61.2) ve yas ortalamaları $72.6 \pm 14.8$ olarak bulunmustur. Her iki grupta yas ve cinsiyet oranları arasında 
anlamlı bir farklılı görülmemiștir. Hastaların ek hastalıkları (Charlson Komorbidite İndeksi (CKI) kullanılmıștır) ve acil servisteki qSOFA skorları benzerdir (Sırasıyla $\mathrm{p}$ değerleri; 0.09-0.11). Her iki grubun hastaneye kabul sırasinda alınan hemogram ve biyokimyasal parametreler, özellikle infeksiyon ile ilișkili olabilecek CRP, prokalsitonin (PCT), laktat değerleri arasında anlamlı bir farklllı görülmemiștir. Hastalara ait tüm laboratuvar parametreleri Tablo 1'de verilmiștir.

Hastaların YBÜ yatıs sebeplerine bakıldığında her iki grupta da en sık endikasyonların sirasiyla pnömoni, KOAH atak ve pulmoner emboli olduğu görülmüstür. YBÜ'de yatan hastalara ait kabul edilme endikasyonları Tablo 2'de verilmiștir.

Hastanemiz EKK'nin el hijyen uyumu ile ilgili aylık gözlemsel verileri incelendiğinde; PÖ 4 aylık dönemde uyum ortalama \%70.62 olarak hesaplanırken, PS 4 aylık dönemde bu oran ortalama
\%82.66 olarak bulundu. Aynı zamanda PS dönemde PÖ döneme göre hastaların ortalama YB yatıs süresi 8.8 'den 7.4 güne düssmüștür. Buna rağmen kullanılan toplam cilt antiseptik miktarının 36 lt'den 70 lt'ye cııtığ $1 \% 94.4)$ görülmüstür. Benzer sekilde kullanılan toplam eldiven miktarının ise 50.000'den 67.000'e (\%34 artıș) çıktığ1 görülmüștür.

Pandemi öncesi grubunda 86 hastadan alınan toplam 605 kültürün 128'inde (\%21) etken üretilirken, PS grubunda 98 hastadan alınan toplam 304 kültürün 31'inde (\%10.2) etken üretilmiștir. PÖ ve PS dönemde etkenlerin çoğu sirasıyla idrar $(n=47 / n=11)$, kan $(n=44 / n=10)$ ve trakeal aspirat $(n=25 / n=7)$ örneklerinden izole edilmistir. Her iki dönemde en çok izole edilen etken Koagulaz Negatif Stafilokok (KNS)'ler olup bunu sırasıyla PÖ dönemde Acinetobacter baumannii, Pseudomonas aeruginosa ve Enterococcus spp.; PS döneminde ise Candida spp., Klebsiella spp.

\begin{tabular}{|c|c|c|c|}
\hline Laboratuvar Parametreleri* & Pandemi Öncesi & Pandemi Sonrası & p \\
\hline Üre (mg/dL) & $\begin{array}{c}76.0 \pm 48.7 \\
66.0(16.0-258.0)\end{array}$ & $\begin{array}{c}77.0 \pm 56.0 \\
58.5(16.0-278.0)\end{array}$ & 0.586 \\
\hline Kreatin $(\mathrm{mg} / \mathrm{dL})$ & $\begin{array}{c}1.4 \pm 1.0 \\
1.0(0.4-6.8)\end{array}$ & $\begin{array}{c}1.4 \pm 0.9 \\
1.1(0.4-5.9)\end{array}$ & 0.709 \\
\hline $\mathrm{Na}(\mathrm{mmol} / \mathrm{L})$ & $\begin{array}{c}138.0 \pm 6.4 \\
138.0(119.0-161.0)\end{array}$ & $\begin{array}{c}139.5 \pm 7.1 \\
139.0(117.0-162.0)\end{array}$ & 0.093 \\
\hline $\mathrm{K}(\mathrm{mmol} / \mathrm{L})$ & $\begin{array}{c}4.3 \pm 0.8 \\
4.3(2.7-6.5)\end{array}$ & $\begin{array}{c}4.3 \pm 0.7 \\
4.2(2.6-6.0)\end{array}$ & 0.507 \\
\hline $\operatorname{ALT}(u / L)$ & $\begin{array}{c}53.1 \pm 94.9 \\
28.0(2.0-615.0)\end{array}$ & $\begin{array}{c}47.8 \pm 73.3 \\
26.5(2.0-473.0)\end{array}$ & 0.778 \\
\hline $\operatorname{AST}(u / L)$ & $\begin{array}{c}101.2 \pm 301.4 \\
29.5(10.0-2246.0)\end{array}$ & $\begin{array}{c}72.5 \pm 138.2 \\
33.0(10.0-1136.0)\end{array}$ & 0.652 \\
\hline CRP $(\mathrm{mg} / \mathrm{L})$ & $\begin{array}{c}94.9 \pm 82.3 \\
72.0(4.0-344.0)\end{array}$ & $\begin{array}{c}96.8 \pm 69.6 \\
87.5(3.0-287.0)\end{array}$ & 0.442 \\
\hline РCТ (ng/mL) & $\begin{array}{c}2.8 \pm 9.3 \\
0.3(0.1-77.0)\end{array}$ & $\begin{array}{c}6.9 \pm 18.7 \\
0.4(0.1-100.0)\end{array}$ & 0.222 \\
\hline Laktat (mmol/L) & $\begin{array}{c}2.4 \pm 2.0 \\
1.6(0.6-12.0)\end{array}$ & $\begin{array}{c}2.4 \pm 1.7 \\
1.9(0.7-11.5)\end{array}$ & 0.263 \\
\hline $\operatorname{Wbc}\left(10^{3} / \mathrm{mm}^{3}\right)$ & $\begin{array}{c}11.4 \pm 4.8 \\
10.3(1.8-22.3)\end{array}$ & $\begin{array}{c}11.0 \pm 5.7 \\
9.6(0.1-30.6)\end{array}$ & 0.298 \\
\hline $\mathrm{Hb}(\mathrm{g} / \mathrm{dL})$ & $\begin{array}{c}12.1 \pm 2.7 \\
12.3(5.0-18.0)\end{array}$ & $\begin{array}{c}12.2 \pm 2.5 \\
12.1(7.3-20.0)\end{array}$ & 0.996 \\
\hline Plt $\left(/ \mathrm{mm}^{3}\right)$ & $\begin{array}{c}230.8 \pm 110.9 \\
209.0(59.0-676.0)\end{array}$ & $\begin{array}{c}209.8 \pm 85.2 \\
196.5(61.0-531.0)\end{array}$ & 0.274 \\
\hline
\end{tabular}

*Değerler ortalama, median ve dağılım aralığı şeklinde verilmiştir. 
Tablo 2. Hastaların yoğun bakım ünitesine kabul edilme endikasyonları

\begin{tabular}{lcccc} 
& \multicolumn{2}{c}{ Pandemi öncesi } & \multicolumn{2}{c}{ Pandemi sonrası } \\
\cline { 2 - 5 } Hastaların yatış tanıları & Sıkık (n) & Oran (\%) & Sıklık (n) & Oran (\%) \\
\hline Pnömoni & 41 & 47.7 & 73 & 74.5 \\
KOAH atak & 19 & 22.1 & 7 & 7.1 \\
Pulmoner emboli & 17 & 19.8 & 3 & 11.3 \\
Akut SVO & 2 & 2.3 & - & 3.1 \\
Kanser & 2 & 2.3 & - & - \\
Epilepsi & 1 & 1.2 & 1 & 1 \\
Üsi & 1 & 1.2 & - & - \\
Hepatotoksisite & 1 & 1.2 & - & - \\
Tüberküloz & 1 & 1.2 & - & 2 \\
Akciğer ödemi & 1 & 1.2 & 2 & 1 \\
Akut renal yetmezlik & - & - & 1 & 100 \\
Kolanjit & - & - & 98 & - \\
Total & 86 & 100 & 3 & \\
\hline
\end{tabular}

SVO: Serebro-vasküler olay, Üsi: Üriner sistem infeksiyonu, KOAH: Kronik obstrüktif akciğer hastalığı.

Tablo 3. Pandemi öncesi ve pandemi sonrası dönemlerde kültürden izole edilen mikroorganizmaların sıklığı ve oranları

\begin{tabular}{lcccc} 
& \multicolumn{2}{c}{ Pandemi öncesi } & \multicolumn{2}{c}{ Pandemi sonrası } \\
\cline { 2 - 4 } Bakteri tipi & Sıklık (n) & Oran (\%) & Sıklık (n) & Oran (\%) \\
\hline KNS & 26 & 20.3 & 10 & 32.4 \\
Acinetobacter baumannii & 18 & 14.1 & - & - \\
Pseudomonas aeruginosa & 18 & 14.1 & 3 & 9.7 \\
Enterococcus spp. & 16 & 12.5 & 3 & 6.6 \\
Escherichia coli & 13 & 10.2 & 2 & 16.2 \\
Candida spp. & 13 & 10.2 & 5 & 12.9 \\
Klebsiella spp. & 6 & 4.7 & 4 & - \\
Aspergillus spp. & 5 & 3.9 & 1 & 3.2 \\
Staphylococcus aureus & 3 & 2.3 & - & - \\
Citrobacter freundii & 3 & 2.3 & - & - \\
Stenotrophomonas maltophilia & 2 & 1.6 & 3 & 9.7 \\
Burkholderia cepacia & - & - & - & - \\
Diğer* & 5 & 3.9 & 31 & 100 \\
Toplam & 128 & 100 & & \\
\hline
\end{tabular}

KNS: Koagulaz negatif stafilokok.

*Proteus mirabilis, Delftia acidovorans, Streptococus spp., Streptococcus pneumoniae, Trichosporon asahii.

ve $P$. aeruginosa takip etmiștir. PS dönemde Burkholderia cepacia haric tüm mikroorganizmaların izolasyon sayıları azalmıs ancak oransal olarak bakıldığında PS dönemde PÖ döneme göre
KNS, Candida spp., Klebsiella spp., B. cepacia ve Staphylococcus aureus izolasyonu artmıstır. PS dönemde hiçbir hastada A. baumannii, Aspergillus spp., Citrobacter freundii ve Stenotrophomonas 
maltophilia izole edilmemiș olup, PÖ döneme göre $P$. aeruginosa, Enterococcus spp. ve Escherichia coli izolasyon oranları azalmıstır. Her iki dönemde kültürden izole edilen tüm etkenlerin sayısal ve oransal olarak karșılaștırılması Tablo 3'te verilmiștir.

En sı izole edilen ilk üc bakteri türü antibiyotik direnci bakımından değerlendirilmiștir. Calıșmamızda PÖ grubunda en sik üretilen etkenler sirasıyla KNS $(\mathrm{n}=26), A$. baumannii $(\mathrm{n}=18)$, $P$. aeruginosa $(\mathrm{n}=18)$ idi. KNS'lerin büyük coğunluğunu (\%41) Staphylococcus epidermidis' in olușturduğu görülmüștür. İzole edilen KNS'lerde metisiline direnc oran1 \%88 olarak bulunmustur. PÖ dönemde izole edilen 18 adet $A$. baumanil susunda karbepenem ve tigesiklin direnc oranları sirasiyla \%83 ( $\mathrm{n}=15)$ ve $\% 17(\mathrm{n}=3)$ olarak bulunmustur. $P$. aeruginosa izolatlarında ise amikasin, gentamisin, imipenem ve meropenem direnc oranları sirasiyla \%22.2 ( $\mathrm{n}=4), \% 27.7(\mathrm{n}=5)$, \%44.4 $(\mathrm{n}=8)$ ve \%39 $(\mathrm{n}=7)$ olarak bulunmuștur.

Pandemi sonrası dört aylı dönemde en sik üretilen etkenler KNS'ler $(\mathrm{n}=10)$ olup bunların üçünün $S$. epidermidis olduğu görülmüstür. Üreyen KNS'lerin metisiline direnc oranı \%80 olarak bulunmustur. $\mathrm{Bu}$ dönemde hicbir hastada $A$. baumannii izole edilmemis ve yalnı üc hastada $P$. aeruginosa izole edilmiștir.

Her iki dönemde alınan kültür sayısı, etken izole edilen kültür sayısı ve alınan kültüre göre üreme yüzdesi hesaplanarak karșllaștırılmıștır; PÖ grubunda tüm parametreler PS grubuna göre istatistiksel olarak anlaml seviyede yüksek bulunmustur (Sekil 1, Tablo 4). Ancak her iki gruptaki hastaların YBÜ'de yatıs süreleri ve mekanik ventilasyonda kalma süreleri arasında anlamlı bir farklılık saptanmamıstır (Tablo 4). İki grup arasında mortalite açısından istatistiksel olarak anlamlı bir fark olmamasına rağmen ( $p>0.05)$ PÖ grubundaki \%33.7'lik mortalite oranının PS grubunda \%23.5'e gerilediği tespit edilmiștir.

\section{TARTIȘMA}

Çalıșmamızda PS döneminde artan el hijyeni uyumuyla birlikte kültürde üreyen etken mikroorganizma oranında belirgin azalma tespit edilmiștir. Ayrıca izole edilen alıșlagelmis etkenlerde değișim dikkat cekicidir.

Günümüzde sağlık harcamalarının artmasının önemli nedenlerinden biri SHil'lerdir. İnfeksiyonların en cok geliștiği yerler ise yoğun bakım

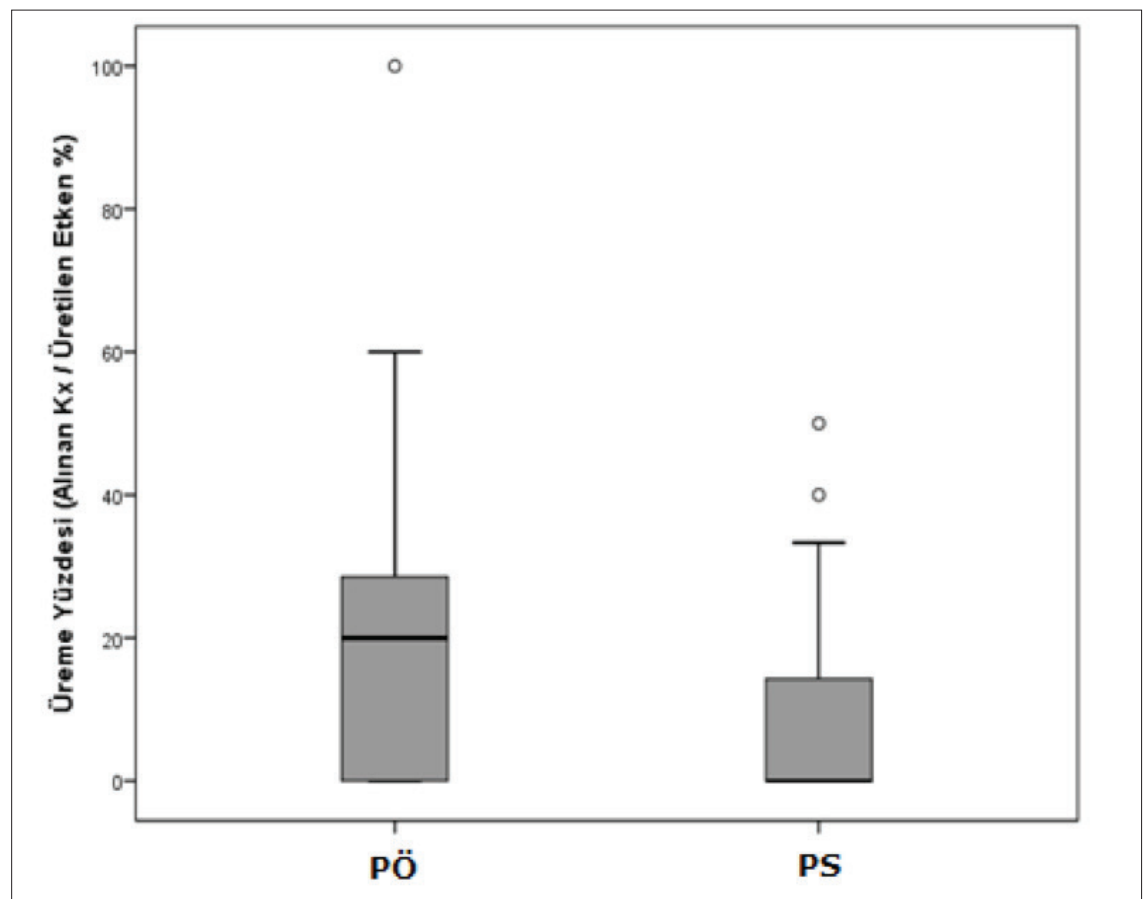

Şekil 1. PÖ ve PS gruplarında alınan kültür sayısına göre izole edilen etkenlerin oransal karşılaştırılması. 


\begin{tabular}{|c|c|c|c|}
\hline & Pandemi Öncesi & Pandemi Sonrası & p \\
\hline Alınan kültür sayısı & $\begin{array}{c}7.0 \pm 6.8 \\
5.5(0.0-30.0)\end{array}$ & $\begin{array}{c}3.1 \pm 3.8 \\
2.0(0.0-22.0)\end{array}$ & $<0.001$ \\
\hline Etken üretilen kültür sayısı & $\begin{array}{c}1.6 \pm 2.0 \\
1.0(0.0-8.0)\end{array}$ & $\begin{array}{c}0.5 \pm 0.9 \\
0.0(0.0-4.0)\end{array}$ & 0.002 \\
\hline $\begin{array}{l}\text { Üretilen etken/alınan kültür } \\
(\%)\end{array}$ & $\begin{array}{c}17.9 \pm 19.0 \\
20.0(0.0-100.0)\end{array}$ & $\begin{array}{c}8.3 \pm 13.1 \\
0.0(0.0-50.0)\end{array}$ & 0.001 \\
\hline Mekanik ventilasyon (gün) & $\begin{array}{c}8.0 \pm 8.0 \\
5.0(1.0-30.0)\end{array}$ & $\begin{array}{c}9.5 \pm 9.6 \\
7.0(1.0-43.0)\end{array}$ & 0.209 \\
\hline YB yatış süresi (gün) & $\begin{array}{c}8.8 \pm 8.9 \\
5.0(1.0-42.0)\end{array}$ & $\begin{array}{c}7.4 \pm 6.4 \\
6.0(1.0-45.0)\end{array}$ & 0.878 \\
\hline Mortalite ${ }^{\star *}$ & $29(33.7)$ & $23(23.5)$ & 0.123 \\
\hline
\end{tabular}

üniteleridir $^{[12,13]}$. Calıșmalarda SHï'lerin morbidite ve mortaliteyi arttırmasının yanı sıra yatıs süresini uzatarak hasta maliyetlerini arttırdığı bildirilmektedir $^{[14,15]}$. SHii gelișen ve gelișmeyen hastaların karșılaștırıldığı bir calıșmada SHIII gelișen bir hastanın maliyetinin gelișmeyen bir hastaya göre 1178.7 dolar daha fazla olduğu tespit edilmiștir ${ }^{[16]}$. SHii'lerin engellenmesinde en basit, en etkin, uygulanabilir kontrol yönteminin el hijyeni uyumu olduğu bilinen bir gerçektir. Sağlık cal1șanlarının kirli ellerinin, bir sağlık tesisi içinde yüksek virulans ve coklu ilac direnci gösteren mikroorganizmaların \%40 oranında hastalar arasında yayılmasına sebep olduğu gösterilmiștir ${ }^{[1,17]}$. Yapılan calıșmalarda SHil'nin sadece el hijyeni uygulaması ile \%30-50 azaltılabileceği gösterilmiștir ${ }^{[18,19]}$. Hem dünyada hem de ülkemizde COVID-19 pandemisi ile birlikte sağlık calıșanları infekte olmamak ve virüsün yayılımını önlemek amacıyla ciddi önlemler almaya bașlamıștır. Bunların bașında el hijyeni uyumundaki artıș gelmektedir ${ }^{[9,10]}$. Calıșmamızda PÖ ve PS 4'er aylık dönemde yoğun bakımda etken üretilen kültür sonuçlarını karșılaștırdığımızda; artan el hijyeni uyumunun sonuçları belirgin oranda değiștirdiğini gözlemledik. Ayrıca el hijyeni uyumunun artısının öncelikle COVID-19'a bağlı gelișen pandeminin sebep olduğu duyarlılık ve endișeye bağlı olduğunu düșuinmekteyiz. Hastanemiz EKK tarafından düzenli olarak takip edilen el hijyeni uyumunun
COVID-19'un ülkemizde görülmeye bașladı̆̆ı Mart 2020'den itibaren önceki aylara göre arttığ1 görülmüștür. Ayrıca hasta sayıları her iki dönemde benzer ve ortalama YB yatıs gün sayısı azalmıș olmasına rağmen, kullanılan eldiven sayısı ve el antiseptiği miktarının belirgin olarak arttığ1 (s1rasiyla \%34-\%94) tespit edildi. Bu durumun da el hijyeni uyumunda artıșın bir göstergesi olarak kabul edilebileceğini düșünmekteyiz.

Calıșmamıza dahil edilen her iki gruptaki hastaların demografik verileri, acilde bakılan qSOFA skorları, ek hastalıklarının siddetini gösteren indeks olan CKI benzer olup aralarında anlaml bir farklılık görülmemiștir. Ayrıca hastaneye kabul laboratuvar parametreleri de benzer olarak tespit edilmiștir (Tablo 1). Bu da bize her iki gruptaki hastaların yatıșları sırasında hastalık siddetlerinin benzer olduğunu düșündürmektedir. YBÜ'de görülen infeksiyonlar genellikle cok ilaca dirençli (CiD) mikroorganizmalar tarafından olușturulduğu için tedavisi zor, tedavi süresi uzun ve maliyeti yuiksektir $^{[16,20]}$.

Yapılan birçok çalıșmada el hijyeni uyumu ile hastane infeksiyonlarının belirgin olarak azaltılabildiği gösterilmiștir ${ }^{[1,21-23]}$. Calıșmamızda PÖ grubunda 86 hastadan alınan toplam 605 kültürün 128 'inde (\%21) etken üretilirken, PS grubunda 98 hastadan alınan toplam 304 kültürün 31'inde (\%10.2) etken üretilmiștir. Alınan kültür sayısı PS grubunda azalmıș olmakla birlikte kültürde üreyen 
etken sayısının anlamlı seviyede azaldığı görülmüștür ( $p<0.001)$. Bu durumun artan el hijyeni ile ilișkili olduğu düșünülmüștür. Harrington ve arkadașlarının Avustralya'da bir hastanede yapmıs oldukları calıșmada el hijyenine uyum \%23'ten \%64.5'e cıktığında, hastane infeksiyon oranında anlamlı bir azalma tespit etmișlerdir [24].

Calıșmamızda her iki grubun hastane yatıs süreleri ve mortalite oranları arasında anlaml bir farkl1lı görülmemiștir. Ancak PS grubunda hastaların büyük coğunluğunu viral pnömoniye sekonder gelișen ARDS'li hastalar olușturmasına rağmen istatistiksel olarak anlamlı olmasa da tedavi süresi ve mortalite oranlarında PÖ döneme göre azalma saptanmıștır. Halbuki ARDS'de mortalite oranı yuiksek olup, yakın zamanda 30 bine yakın hastayı kapsayan cok merkezli bir calıșmada siddetli ARDS'de mortalite oranı \%46 olarak bildirilmiștir ${ }^{[25]}$. Bu durum el hijyeni uyumunun artıșına bağlı olarak SHï sıklığının azalması ile ilișkili olabilir. Ayrıca ARDS tedavisinin en önemli kısmını mekanik ventilasyon olușturmasına rağmen her iki grubun mekanik ventilasyon süreleri benzer olarak görülmüștuir $(p=0.209)$.

Yapılan birçok calıșmada yoğun bakımlarda CíD ajanlardan en sik $A$. baumannii ve $P$. aeru ginosa izole edilmiștir ${ }^{[26-28]}$. Bizim çalıșmamızda ilk sırada KNS'ler yer almıștır. Ancak KNS'lerin büyük coğunluğunu (\%41) S. epidermidis olușturması sebebi ile öncelikle cilt bulașının sorumlu olabileceği düșünülmüștür. Bununla birlikte PS dönemde PÖ dönemine göre KNS üremelerinde belirgin azalma olması artan el hijyeni uyumu ve kültürlerin daha usulüne uygun alınmasının sonucu olarak kontaminasyonun azalması seklinde yorumlanmıstır. Ayrıca PS dönemde coğu COVID-19 hastasında bakteriyel koinfeksiyon ön planda düșuinülmediği için daha az kültür alınması, genel olarak üremelerin azalması ile ilișkili olabilir. Çalıșmamızda PÖ dönemde izole edilen 18 adet $A$. baumanii susunda karbepenem ve tigesiklin direnc oranları sirasıyla \%83 ( $n=15)$ ve $\% 17 \quad(n=3)$ olarak bulunmuștur. Aynı sayıda olan $P$. aeruginosa izolatlarında ise amikasin, gentamisin, imipenem ve meropenem direnç oranları sirasıyla \%22.2 ( $n=4), \% 27.7 \quad(n=5), \% 44.4$ $(n=8)$ ve \%39 ( $n=7)$ olarak bulunmuștur. Ece ve arkadașlarının yakın zamanda yapmıs oldukları bir çalıșmada bizim çalıșmamız ile benzer sekilde
$P$. aeruginosa'nin amikasin ve gentamisin direnç oranları sirasıyla \%28, \%25 olarak bulunurken, karbepenem direnci çalșmamızdan daha düșük (\%13.4) olarak bulunmuștur ${ }^{[29]}$. Aynı çalıșmada $A$. baumanii izolatlarında karbapenem direnci \%56.7 olarak bizim calıșmamızdan duișuik bulunurken, tigesiklin direnci yüksek (\%30.8) olarak bulunmuştur ${ }^{[29]}$. Hamzeh ve arkadașlarının İran'da yaptıkları bir calıșmada Acinetobacter spp. izolatlarında imipenem ve meropenem direnci bizim calıșmamı ile benzer olarak \%86.62 ve \%99.75 bulunmustur ${ }^{[30]}$. PS 4 aylık dönemde yine en sik üretilen etkenler KNS'lerdi ve yine PÖ grubu ile benzer olarak \%40'ını S. epidermidis olușturmuștur. PÖ ve PS grubunda metisiline direnç oranları sirasıly \%88 ve \%80 olarak tespit edilmiștir. Ünlü ve arkadașlarının ceșitli klinik örneklerden izole ettikleri KNS sușlarında metisilin direncini bizim çalısmamızdan düsüuk olarak \%44 oranında bildirirlerken, bașka bir calıșmada calıșmamızla benzer olarak metisilin direnci \%74 oranında bulunmustur ${ }^{[31,32]}$. PS dönemde istatistiksel olarak anlamlı olmamasına rağmen mekanik ventilasyon entübe gün sayısı PÖ gruba göre daha fazla olmasına rağmen hiçbir hastada $A$. baumannii izole edilmemiș, yalnız 3 hastada $P$. aeruginosa üretilmiștir. Bu sonucun öncelikle el hijyeni uyumundaki artıs ile ilișkili olabileceği düșünülmüștür. Ayrıca COVID-19 seyrinde bakteriyel koinfeksiyonlar daha az gözlenmiștir. Bu durumun farkında olmanın akılcı antibiyotik kullanımına katkı sağlayacağı kanaatindeyiz. PÖ ve PS dönemdeki antibiyotik direnç oranları karșılaștırıldığında aralarında KNS için anlamlı bir fark yokken, PS döneminde izole edilen $A$. baumanii $(\mathrm{n}=0)$ ve $P$. aeruginosa $(n=3)$ saylları sebebi ile istatistiksel karșılaștırma yaplamamıștır. Bu durum iki dönemin birbirini takip etmesine ve çalsșmaya dahil edilen PÖ ve PS sürelerinin antibiyotik direnç oranlarını etkileyecek kadar uzun olmamasına bağlanmıștır.

\section{SONUÇ}

Sonuc olarak her ne sebeple olursa olsun, el hijyeni uyumundaki artıs kültürlerde üreyen etken mikroorganizma ve dolayl olarak SHï'lerin azalmasına katkı sağlayabilmektedir. Bu nedenle özellikle YBÜ'deki ÇID infeksiyonların önlenmesi için öncelikle sağlık çalıșanlarının el hijyeni uyumu sağlanmalıdır. Bu bağlamda yapılan infeksiyon kontrol programında tüm hastane personeline eği- 
timlerin belli aralıklarla tekrar edilmesi, el hijyen uyumunun sık gözlenmesi, YBÜ'nün fiziki koșullarının uygunluğu ve güvenilir etkili temizlik ürünlerinin kullanılması SHil'lerin azaltılmasında temel öneme sahiptir.

\section{ETIK KURUL ONAYI}

Çalıșma için Erzincan Binali Yıldırım Úniversitesi Klinik Araștırmalar Etik Kurulu tarafından 28/01/2021 tarihli ve 03/01 sayılı kararıyla onay almiștir.

\section{ÇIKAR ÇATIȘMASI}

Yazarlar bu makale ile ilgili herhangi bir c1kar çatıșması bildirmemișlerdir.

\section{YAZAR KATKISI}

Anafikir/Planlama: MT, SA, HÖ

Analiz/Yorum: MT, UDB, FK

Veri Sağlama: MT, SA, FK

Yazım: MT, UDB, SA, HÖ, FK

Gözden Geçirme ve Düzeltme: MT, UDB,

SA, FK

Onaylama: FK

\section{KAYNAKLAR}

1. Rahmet Ç. El Hijyeni. Hastane Infeksiyonları Derg 2007; 11:54-9.

2. Siegel JD, Rhinehart E, Jackson M, Chiarello L. 2007 Guideline for Isolation Precautions: Preventing Transmission of Infectious Agents in Healthcare Settings (updated July 2019) https://www.cdc.gov/infectioncontrol/guidelines/isolation/ index.html. Cdc. 2019;1-232.

3. Rathore $\mathrm{MH}$, Jackson MA. Infection prevention and control in pediatric ambulatory settings. Pediatrics 2017; 140(5):e20172857.

4. Kaymakçı H, Özcan A. El Hijyeni. Klimik Derg 2007;20(2):39.

5. Girou E, Loyeau S, Legrand P, Oppein F, Brun-Buisson C. Efficacy of handrubbing with alcohol based solution versus standard handwashing with antiseptic soap: Randomised clinical trial. BMJ 2002;325(7360):362.

6. McNeil SA, Foster CL, Hedderwick SA, Kauffman CA. Effect of hand cleansing with antimicrobial soap or alcohol-based gel on microbial colonization of artificial fingernails worn by Health Care Workers. Clin Infect Dis 2001;32(3):367-72.

7. Walker JL, Sistrunk WW, Higginbotham MA, Burks K, Halford $L$, Goddard $L$, et al. Hospital hand hygiene compliance improves with increased monitoring and immediate feed back. Am J Infect Control 2014;42(10):1074-8.

8. Srigley Dr JA, Furness C, Baker GR, Gardam M. Quantification of the hawthorne effect in hand hygiene compliance monitoring using an electronic monitoring system: A retrospective cohort study. BMJ Qual Saf 2014;23(12):974-80.
9. Uğurlu YK, Durgun H, Nemutlu E, Kurd O. Assessment of knowledge and attitude of social handwashing in Turkey population during COVID-19 pandemic. I Contemp Med 2020;10(4):617-24.

10. Lan J, Song Z, Miao X, Li H, Li Y, Dong L, et al. Skin damage among health care workers managing coronavirus disease-2019. J Am Acad Dermatol 2020;82(5):1215-6.

11. European Committee on Antimicrobial Susceptibility Testing (EUCAST),2020. Testing breakpoint tables for interpretation of MICs and zone diameters, version 10.0. p. http:// www.eucast.org/clinical_breakpoints/.

12. Weber DJ, Raasch R, Rutala WA. Nosocomial infections in the ICU: The growing importance of antibiotic- resistant pathogens. Chest 1999;115(3 Suppl):34S-41S.

13. Daschner F. Nosocomial infections in intensive care units. Intensive Care Med 1985; 11(6):284-7.

14. Pittet D, Allegranzi B, Storr J, Donaldson L. "Clean Care is Safer Care": the Global Patient Safety Challenge 2005 2006. Int J Infect Dis 2006;10(6):419-24.

15. Boyce JM, Pittet $D$. Guideline for hand hygiene in health-care settings: Recommendations of the Healthcare Infection Control Practices Advisory Committee and the HICPAC/ SHEA/APIC/IDSA Hand Hygiene Task Force. Society for Healthcare Epidemiology of America/Association for Professionals in Infection Control/Infectious Diseases Society of America. MMWR Recomm Rep 2002;51 (RR-16):1-45, quiz CE1-4.

16. Akkuş MN, Biberoğlu K. Yoğun bakım unitesi infeksiyonlarının hasta maliyetine etkisi. ANKEM Derg 1995;9(2):175.

17. Boyce JM, Pittet D. Guideline for Hand Hygiene in Health-Care Settings: Recommendations of the Healthcare Infection Control Practices Advisory Committee and the HICPAC/SHEA/APIC/IDSA Hand Hygiene Task Force. Infect Control Hosp Epidemiol 2002;23(S12):S3-40.

18. Pittet $D$, Hugonnet $S$, Harbarth $S$, Mourouga P, Sauvan V, Touveneau S, et al. Effectiveness of a hospital-wide programme to improve compliance with hand hygiene. Lancet 2000;356(9238):1307-12.

19. Arda B, Şenol Ş, Taşbakan MI, Yamazhan T, Sipahi OR, Arsu $\mathrm{G}$, et al. Ege Üniversitesi Tıp Fakültesi Yoğun Bakım Ünitelerinde El Temizliği Kurallarına Uyumun Değerlendirilmesi. Yoğun Bakım Derg 2005;5(3):182-6.

20. Yalçın AN. Yoğun bakım ünitesinde antibiyotik kullanımı ve direnç sorununa genel bakış. ANKEM Derg 2009;23(Ek 2):136-142

21. Hugonnet S, Perneger TV, Pittet D. Alcohol-based handrub improves compliance with hand hygiene in intensive care units. Arch Intern Med 2002;162(9):1037-43.

22. Randle J, Clarke M, Storr J. Hand hygiene compliance in healthcare workers. J Hosp Infect 2006;64(3):205-9.

23. Lucet JC, Rigaud MP, Mentre F, Kassis N, Deblangy C, Andremont $A$, et al. Hand contamination before and after different hand hygiene techniques: A randomized clinical trial. J Hosp Infect 2002;50(4):276-80. 
24. Harrington G, Watson K, Bailey M, Land G, Borrell S, Houston $L$, et al. Reduction in Hospitalwide Incidence of Infection or Colonization with Methicillin-Resistant Staphylococcus aureus With Use of Antimicrobial Hand-Hygiene Gel and Statistical Process Control Charts. Infect Control Hosp Epidemiol 2007;28(7):837-44.

25. Silvia Valente Barbas C, Fittipaldi Palazo R, Faissol Janot de Matos G. Severe Acute Respiratory Distress Syndrome. In: Advances in Extra-corporeal Perfusion Therapies. IntechOpen; 2019 [cited $2020 \mathrm{Feb} 22$ ]. Available from: https:// www.intechopen.com/books/advances-in-extra-corporeal-perfusion therapies/severe-acute-respiratory-distress-syndrome

26. Cikman A, Gundem NS, Karakeçili F, Korkmaz E, Cikman O. Microorganisms Isolated from Various Clinical Samples of Intensive Care Unit Patients and their Antibiotic Susceptibilities. ANKEM Derg 2012;26(3):131-6.

27. Gazi H, Sürücüoğlu S, Kurutepe S, Inmez E, Dinç G, Özbakkaloğlu $B$. Yoğun bakım ünitesi ve diğer ünitelerde yatan hastalardan izole edilen Acinetobacter baumannii suşlarında in vitro antibiyotik direnci. ANKEM Derg 2005;19(3):115-8.

28. Jordan Garcia I, Esteban Torné E, Bustinza Arriortua A, De Carlos Vicente JC, García Soler P, Concha Torre JA, et al. Trends in nosocomial infections and multidrug-resistant microorganisms in Spanish pediatric intensive care units. Enferm Infecc Microbiol Clin 2016;34(5):286-92.
29. Ece G, Ece C, Aslan D. Evaluation of Antimicrobial Resistance Profile and Risk Factors of Acinetobacter Baumannii and Pseudomonas Aeruginosa Strains Isolated at Intensive Care Patients. Balıkesir Med J 2020;4(3):46-54.

30. Hamzeh A, Rezaee P, Mohammadi M. Acinetobacter baumannii antibiotics resistance in Iran. I Bacteriol Mycol 2019;7(6):159-62.

31. Ünlü VG, Ünlü $M$, Yağmuroğlu A. Klinik örneklerden soyutlanan Staphylococcus aureus ve koagülaz negatif stafilokok izolatlarında mupirosin direnci. ANKEM Derg 2006;20(4):222-5.

32. Ertürk A, Çiçek AÇ, Köksal E, Köksal Zş, Özyurt S. Yoğun bakım ünitesinde yatan hastaların çeşitli klinik örneklerinden izole edilen mikroorganizmalar ve antibiyotik duyarlılıları. ANKEM Derg 2012;26(1):1-9.

\section{Yazıșma Adresi/Address for Correspondence} Dr. Faruk KARAKEÇİLI

Erzincan Binali Yıldırım Üniversitesi Tıp Fakültesi, İnfeksiyon Hastalıkları ve Klinik Mikrobiyoloji Anabilim Dalı, Erzincan-Türkiye

E-posta: drfarukkarakecili@hotmail.com 